\title{
The economic-political concept of Hizbut Tahrir Indonesia: reflection on the early Islamic thoughts
}

\author{
Nafis Irkhami \\ State Institute of Islamic Studies (STAIN) Salatiga, Indonesia \\ E-mail:nafis_ir@yahoo.com
}

\begin{abstract}
Hizbut Tahrir (The Party of Liberation) is an international pan-Islamic politica 1 organization. Its goal is to unify all Muslim countries as an Islamic state (caliphate) ruled by shariah. They argued that caliphate and Islamic law should not be separated. Without a caliphate, the sharia application will never be totally accomplished. Factually, these grand themes constitute the global discourse applied by Hizbut Tahrir movements around the world. It becomes the main idea that links their global ideological ground and commonality. Hizbut Tahrir (HT) entered into Indonesia in 1982, through M. Mustofa and Abdurrahman al-Baghdadi. As in another countries, HT got repression from the government. Using a momentum of the reformation era, Hizbut Tahrir Indonesia (HTI) begin to socialize its ideas openly. Even in 2000, they have registered its organization at the Ministry of Domestic Affairs.

This study aims to scrutinize the ideas of HTI thinking about political economy, which is devoted to the theory about the relationship between religion, state and economy, as well as the construction of public finances. This study is intended as a historical study of Islamic economic thought. The discourse of the study focuses on three questions. First, how does HTI grow in Indonesia, and why does they flourish? Second, what are the relationship between the
\end{abstract}


religion, the state and the economy according to them? Finally, how is the structure of HTI's public finances?

This qualitative study was an exploratory-analysis. It was intended to analyze key concepts in a plantation of thought that has been documented, both from primary and secondary sources. It is a library research. The sources of the research are in the form of HTI's works which have been well documented in a large numbers, including in the Pdf formats. The study found that HTI tended to see every current economic problem by reflecting it into the cultural heritage of the past. Related to this, the slogan that they have always been shouted was "Sharia is the only solution." From this philosophy it can be estimated that HTI's thoughts of Islamic public finance, will face the problem of contextualization.

Hizbut Tahrir (Partai Kemerdekaan) adalah sebuah gerakan politik Islam internasional. Tujuannya adalah untuk menjadikan negara-negara Muslim dalam satu kepemimpinan negara Khilafah yang diatur dengan syariah. Mereka berpendapat bahwa kekhalifahan dan hukum Islam tidak dapat dipisahkan. Tanpa Negara khilafah, syariah tidak dapat diterapkan dengan sempurna. Gagasan utama inilah yang diusung oleh Hizbut Tahrir di seluruh dunia. Gagasan pokok itulah yang mempertemukan idiologi dan pergerakan mereka. Hizbut Tahrir masuk ke Indonesia pada tahun 1982 melalui M. Mustofa dan Abdurrahman al-Bagdadi. Sebagaimana di negara-negara lain, HT mendapat tekanan dari pemerintah. Dengan memanfaatkan momentum era reformasi, HTI mulai mensosialisasikan ide-idenya secara terbuka. Bahkan pada tahun 2000 mereka telah mendaftarkan dirinya sebagai organisasi resmi di Depdagri Ditjen Kesatuan Bangsa.

Studi ini bertujuan untuk mengungkap gagasan pemikiran HTI tentang ekonomi politik, khususnya mengenai teori hubungan antara agama, negara dan perekonomian, serta mengenai konstruksi keuangan publik. Kajian ini dimaksudkan sebagai studi historis tentang pemikiran ekonomi Islam. Pokok masalah dalam penelitian ini adalah: Pertama, bagaimana HTI tumbuh dan berkembang di Indonesia. Kedua, bagaimanakah hubungan antara agama, Negara dan perekonomian menurut mereka. Ketiga, bagaimanakah struktur keuangan public menurut HTI?

Kajian kualitatif ini bersifat eksploratif-analisis, yakni dimaksudkan untuk 
mengurai dan menganalisa secara mendalam mengenai konsep-konsep kunci dalam pemikiran HTI yang telah terdokumentasikan, baik dari sumber primer maupun sekunder. Berdasar sifatnya, penelitian ini termasuk library research, di mana bahan dan sumber data penelitian ini berupa karya-karya dari tokohtokoh HTI yang telah terdokumentasikan dengan baik dalam jumlah besar, termasuk dalam format Pdf. Penelitian ini menemukan bahwa HTI cenderung melihat segala persoalan ekonomi saat ini dengan merefleksikannya pada warisan budaya masa lalu. Terkait dengan hal ini, slogan yang selalu mereka teriakkan adalah "Syariah adalah satu-satunya solusi." Dari cara berfikir ini dapat diperkirakan bila pemikiran-pemikiran keuangan publik HTI akan menghadapi problem kontektualitas.

Keywords: Islamic economic; Politics; Public finance; Hizbut Tahrir Indonesia

\section{Introduction}

The formalization of Islamic law (sharia) in Indonesia has been getting significant growth since the post-reform era. It was started by the escalation of political euphoria and freedom of expression. The freedom conditions of religious expression in Indonesia have been developing since the end of the New Order in 1998. The situation was utilized by some organizations to seek for the formalization of Islamic law.

The organizations that fight for Islamic ideology have many differences with the older Indonesian Islamic movements (Nahdatul Ulama, Muhammadiyah, Persis, al-Ershad, and so on). Their movements were kept "out line" or took a distance from official politics. Hizbut Tahrir Indonesia (HTI), MMI, FPI, Laskar Jihad and Salafis are the representation of the new model of the Islamic movements in Indonesia.

Those contemporary Islamic organizations have ideology, thought and movement strategies which are different from the existing Islamic groups. They tend to be puritant, militant, scripturalist, conservative and exclusive. Among these organizations, HTI, as the object of this study, is the 
most solid and has the widest network. As a trans-national organization, their political ideology is very radical, because they do not have merely an aspiration to uphold Islamic law, but also to establish an Islamic government (Khiläfah Islämiyah). ${ }^{1}$ According to them, the total enforcement (kâffah) of Islamic law (sharia) can only be realized in a certain system. Shari'a which governs public interests, such as criminal law (hudū $\bar{d}$, jināyah, ta'zir), political system, economy, and education, can only be performed by a caliph, not by the president or the prime minister. ${ }^{2}$

Hizbut Tahrir got repression in all countries, including Jordan, the country of origin initiators, since they have a very strict ideology. It only could grow formally in Indonesia. From the beginning of its formation in 1982 until the end of New Order (1998s), HTI was always under the pressure. They used the momentum of the reformation era of openness and freedom to preach and disseminate its ideas to the general public. Their proselytizing idea was indicated by the held of International Khilafah Conference in Senayan on May 28, 2000. Even after that, they had also registered them self as an official organization at the Ministry of Home Affairs Directorate General for National Unity in Jakarta. ${ }^{3}$

Adhering to Robinson who stated that one of the economic system components is the ideological justification, ${ }^{4}$ it can be understood that HTI's political economic activities are the part of religious ideology ex-

${ }^{1}$ Team of Hizbut Tahrir, Mengenal Hizbut Tahrir Partai Politik Islam Idiologis, Bogor: Pustaka Thariqul Izzah, 2002, 23-25. See also, Houriya Ahmed dan Hannah Stuart, Hizb ut-Tahrir, Ideology and Strategy, London: The Centre for Social Cohesion, 2009, 13.

${ }^{2}$ Muhammad Iqbal Ahnaf, "MMI dan HTI; The Image of The Others," in A. Maftuh Abegebriel and A. Yani Abeveiro, (ed.), Negara Tuhan: the Thematic Encyclopedia, Yogyakarta: SR-Ins, 2004, 698-699.

${ }^{3}$ Ainur Rofiq al-Amin, Membongkar Proyek Khilafah ala Hizbut Tahrir di Indonesia, Yogyakarta: LKiS, 2012, 4.

${ }^{4}$ He stated that the components of economics system consists of: 1) a set of rules; 2) an ideology to justify them; (3) a conscience the individual which makes him strife to carry them out. See, Mubyarto, Pemberdayaan Ekonomi Rakyat dan Peranan Ilmu-Ilmu Sosial, Yogyakarta: BPFE, 2002. 
pression. Religious expression in the economic behavior becomes an important part of the economic tenets. For them, Islamic economic system could only be realized if the prevailing political system was in line with the Islamic ideology. ${ }^{5}$

The explanation shows that HTI's theory of the political economy is unique in comparation with any economic system. It was even different when it was compared with the theories of Islamic economic system that already exists. Thus, the study of HTI political economy thought, particularly on public economics, is important and relevant. This could be understood because the political economic theory becomes the basic for the whole series of economic activities in a country. As a religious movement that has been growing rapidly, HTI has played such a role in the development of economic political thought in Indonesia.

Based on the description above, the main issue of this study is what is the relationship between religion, state and economy according to HTI? What is the basic mandate and maintenance of public finances according to them? As a historical development study of the of Islamic economic thought, the benefits of this research are expected to provide an objective description of how HTI's economists responded to the political economy issues. At the same time, it also means to acknowledge their contributions. It is from the appropriate and objective understanding of the construction of their thinking, this research can be used as an improvement on similar research themes.

\section{Previous researches}

Studies of HTI that have been done could be broadly categorized into the organization movement and ideology studies. The objects of the movement studies were from sociological, anthropological and social psycho-

\footnotetext{
${ }^{5}$ Anonim, Manifesto Hizbut Tahrir untuk Indonesia. Np.: HTI, 2009, 12.
} 
logical perspectives. Their goal was to scrutinize the movement in the facets of its dynamics, patterns of recruitment, organizations follower typology, inclusivity and exclusivity perceptions. The second type of research studies was on its ideology and ideas derived from the concept of Khilafah.

Generally, the first type of the study was conducted by outsiders. Generally they highlighted HTI as the Islamic fundamentalist movement which was anti-democratic and anti-Western movement (anti-American movement). However, most of these studies also found that although the HTI's movement categorized as fundamentalism, their actions was established peacefully, and avoid of physical violences. This can be understood from their recent actions. Its orientation target is to promote their ideas of the urgency to return to chaliphate and Islamic principles and to build awareness among Indonesian Muslim. Moreover, the violence can only be done by the caliphate himself. While the current phase of the HT struggle has not entered the formation of a dawla yet. ${ }^{6}$ That is why they do not justify the use of violence means.

The first category of the study above had been carried out by M. Imdadun Rahmat. ${ }^{7}$ In his research, he also used the Muslim Brotherhood and Tablighi Jamaat as the object study. Their religious movement had been imported from the Middle East. Rahmat focused his research on the transmission of the Islamic movements from the Middle East to Indonesia, and early growth in Indonesia in the 1980s. This historical study was described the transformation process of HT to Indonesia. Researcher does not use HT actions to enforce Islamic law as an object of research.

${ }^{6}$ Taqy al-Din An Nabhany, Nižām al-sslām, Beirut; Dār al-Ummah, 2001, 84. See also, 'Abd al-Qadim Zallum, The Methodology of Hizbut Tahrir for Change, London: al-Khilafah Publications, 1993.

${ }^{7}$ M. Imdadun Rahmat, Arus Baru Islam Radikal: Transmisi Revivalisme Islam Timur Tengah ke Indonesia, Jakarta: Erlangga, 2005. 
The question that arise from reading about the transformation of HT to Indonesia is how they promote the pattern and strategy development as well as their ideology. One of the study that tried to unravel it was done by Zuly Qadir. ${ }^{8}$ He classified HT as an Islamic fundamentalism. Qadir discussed about Islamic fundamentalism. It is especially focused on the causes and characters of the movement. Islamist groups which are categorized as fundamentalism are MMI, FPI, FKAWJ and HTI itself. He does not discuss each of these groups specifically. The researchers do not examine the empirical aspects, but more about the phenomenon of religious fundamentalism in general.

The qualitative study, which also seeks to explain religious fundamentalism, is done by Haedar Nasir. ${ }^{9}$ This study focuses on the enforcement of Islamic law movements and parties which are trying to enforce Islamic law. The quantity objects of this study are intended to obtain a generalization of phenomenon of Islamic shariah militancy in Indonesia. In accordance to the purpose of the study, Haedar does not examine the field actions of these organizations in realizing the establishment of Islamic law. Especially with regard to HTI, he mostly focuses on an idea about the importance of enforcing Islamic law and the concept of the caliphate that would overarched implementation of Islamic law. In this regard, he analyze it using the perspective of Islamic theology. However, his historical data are in contradictory to many other studies as well as the official writings issued by HTI.

Arifin did a qualitative research that focuses on the HTI movement as "religious fundamentalism." 10 This research found that HTI was a

${ }^{8}$ Zuly Qodir, "Fundamentalisme Islam, Memahami Penyebab dan Karakter Gerakan" in Potret Retak Nusantara: Studi Kasus Konflik di Indonesia, Yogyakarta: CSPS, 2004.

${ }^{9}$ Haedar Nashir, Gerakan Islam Syariat: Reproduksi Salafiyah Ideologis di Indonesia, Jakarta: PSAP Muhammadiyah, 2007.

10 Syamsul Arifin, Obyektivikasi Agama sebagai Ideologi Gerakan Sosial Kelompok Fundamentalis Islam, Studi Kasus Hizbut Tahrir Indonesia di Kota Malang), Ph.D Thesis at IAIN Sunan Ampel, Surabaya, 2004. 
"religiopolitic-universalistic" movement. It has two elements, namely the idea (fikrah) and methods (tariqah). The idea element contains an explanation of faith, while the other includes the procedures for implementing, maintaining, and disseminating aqidah and Islamic law.

Ainur Rofiq, a former member of Hizbiyyun, accomplished a similar study which focused on the meanings, concepts, definitions, characteristics, metaphors, symbols and descriptions of HTI on the Caliphate State. Finally he stated that the idea of the caliphate can reduce the survival of the nation and state of Indonesia. Therefore it needs awareness and review of the timber. The caliphate system is not just being a quasi-Islamic, but rather as a false conciousness. ${ }^{11}$

The next qualitative research was conducted by Ilyya Muhsin. His theme of the study was about HTI's idea to enforce Islamic Shari'a in Yogyakarta. ${ }^{12}$ This ethnographic study was intended to reveal the efforts made by HTI to enforce Islamic law in Yogyakarta. He found that, first, HTI exploited political reform opportunities to change their stategy, from an underground movement to the legal action so that they could do it freely. Second, mobilizing internal and external structures. The internal mobilization was done by coaching cadre, while the second one was conducted awareness and urgency about compulsory enforcement of Islamic law as well as the caliphate. Third, the preparation process of the movement was done by developing a discourse to reject any thought and system which came from the West, such as democracy, nationalism and human rights. For example, their political attitude was to refuse the vote in the election, to reject the use of Indonesia's state symbols, and so on.

${ }^{11}$ Al-Amin, Membongkar Proyek Khilafah..., 206.

${ }^{12}$ Ilyya Muhsin, "Gerakan Penegakan Syariat Islam; Studi tentang Gerakan Sosial Hizbut Tahrir Indonesia di DIY”, Yogyakarta: Thesis of Sociology Programme of Gadjah Mada University, 2007. 
A comparative study which had similar focus with Muhsin was conducted by Iskandar Zulkarnain. ${ }^{13}$ It was focused on the symbolic power arena of Hizbut Tahrir Indonesia (HTI) and Majelis Mujahidin Indonesia (MMI). He analyzed the formalization of Islamic law by using Pierre Bourdieu's conceptual framework consisting of the concept of habitus, arena fight (champ), and symbolic power.

A comparative study with the same objects (HTI and MMI), was conducted by Mohammad Iqbal Ahnaf. ${ }^{14}$ He examined how both organizations looked at individuals or groups outside them in the matter of religious salvation. Using textual understanding and scriptual, both groups considered outsiders as deviate from the truth. They considered nonMuslims as the main enemy who had always tried to destroy Islam. It should be used empirical datas, because it tried to describe perception.

The similar study was conducted by Ihsan Yilmaz. ${ }^{15}$ In his research, Yilmaz tries to unravel a question; why in autocratic countries, such as Egypt and Turkey, HT has no significant influence for young people. Meanwhile, in the UK and Uzbekistan, they easier to be accepted among young generation. He concluded that their development in the four countries experienced significant differences. That was due to the different of their background of socio-political-economic and theology. According to him, the most significant condition which affecting the acceptance and development of HT in the four countries was theological vacuum condi2009.

${ }^{13}$ Thesis presented at Sociology Programme of Gadjah Mada University, Yogyakarta,

14 “The Image of the Enemy, Fundamentalist Muslims' Perceptions of the Other (Majelis Mujahidin Indonesia and Hizbut Tahrir Indonesia)," Thesis presented at Postgraduate Programme of Center for Religious and Cross-Cultural and Studies, Universitas Gadjah Mada, 2004.

${ }^{15}$ Ihsan Yilmaz, "The Varied Performance of Hizb ut-Tahrir: Succes in Britain and Uzbekistan and Stalemate in Egypt and Turkey," in Journal of Muslim Minority Affair, vol. 30, No. 4 (Desember 2010). 
tions. In such countries, ideological enforcement of Islamic law is more readily accepted and can be developed properly.

Kirstine Sinclair did a research on HT as a trans-national organization. ${ }^{16}$ The researcher tried to unravel the elements of the trans-national movement of HT, and the dialectic relations between these elements within the Khilafah framework. The combination of historical-hermeneutic and sociological approaches had been used to explain how HT was accepted in Denmark and the UK. That was due to the hybrid organization between the cadre member, social movements, and the "tribal" sense. The same research theme was repeated by Umi Iqbal Sumbulah. ${ }^{17}$ This was an exploration research of HTI and MMI activities in Malang, East Java. The study tried to understand their point of views about Christianity and Jew in the matters of religious pluralism, liberal Islam, and religious violence, including their efforts to construct such issues.

Iqbal focused to HTI was developed further by writing a dissertation entitled From Revolution to "Refolution": A Study of Hizb al-Tahrir, Its Changes and trajectories in the Democratic Context of Indonesia. ${ }^{18}$ This study aimed to capture the HTI's political movement strategy "anti-system". They use the strategy in accordance with the main reason that the Caliphate system does not recognize the state category (Indonesia) and the democratic system.

Research on HTI as a fundamentalist movement was also done by Hendra Kurniawan. ${ }^{19}$ It discussed about hegemonic discourse and praxis ideology of Hizb ut-Tahrir in Indonesia. He tried to found a map of Islamic fundamen-

${ }^{16}$ Centre for Comtemporary Middle East Studies Institute for History and Civilization, Ph.D Thesis at University of Southern, Denmark, 2010.

${ }^{17}$ Umi Sumbulah, "Islam Radikal dan Pluralisme Agama: Studi Konstruksi Sosial Aktivis Hizb al-Tahrîr dan Majelis Mujahidin di Malang tentang Agama Kristen dan Yahudi”, Ph.D Thesis at IAIN Sunan Ampel Surabaya, 2007.

${ }^{18} \mathrm{Ph} . \mathrm{D}$ Thesis at Program Strategic Studies, Victoria University of Wellington, New Zealand, 2010.

${ }^{19}$ Thesis at the Middle East and Islamic Studies Program of Indonesia University, 2003. 
talism political movement in Indonesia. The examined issues were the extent of transformation or the change of HTI's identity in the socio-political interaction in Indonesia. A significance of this anthropological study was to reveal the context of interaction continuity and awareness to make a change among HTI members.

The only study that focused on HTI's economic rationale was done by Shihab. ${ }^{20}$ This comparative study was intended to capture the differences between Indonesian economic systems and HTI's perspective. The main issues were the system of production, distribution and consumption. The conclusion from this study was that both have a very different concept since they have different epistemological foundation. In fact, this conclusion shows that the comparative study was not appropriate to be done, because the comparation objects were not as fair as "apple to apple".

Based on the exploration of previous studies above, it appeared that almost all researchers were more interested in discussing HT as a "fundamentalist" organization. Depth study of the concepts and their economic thought has not been done, particularly about political economic thoughts. Meanwhile, according to the recognition of a chairman of regional board (DPD HTI), they are actually more appreciate to the research of HTI ideas and thoughts as the objects of study rather than discussing about it's movements and organizations aspects. He considered such kind of studies as "intervene to other household." 21

\section{Research method}

This study aims to find HTI's thinking about the concept of Islam as a political economic science, especially concerning with public policy. This qualitative exploratory-analysis study was intended to analyze main con-

\footnotetext{
${ }^{20}$ Thesis at The Islamic Studies Program of Islamic University of Indonesia, 2010.

${ }^{21}$ An Interviewed with Ir. H. A. Fadholi (Chairman of Regional Board of HTI Solo Raya), $1^{\text {st }}$ November 2012.
} 
cepts of economical politic thoughts, both from primary and secondary sources. ${ }^{22}$ Explorative research-analysis in this case refers to the meanings, concepts, definitions, characteristics, metaphors, symbols, and descriptions. ${ }^{23}$ Based on its nature, this research can be classified as a library research, in which the source material and research data in the form of the HT's works which have been documented in the large numbers.

The selection of this model was based on the consideration that a configuration of thoughts would be better and easier to understand from the published works. In another words, the way of thinking that has been disclosed in the written works were much more organized in a systematic and coherent than the spoken language. Based on these, the researcher felt sufficient to the literary data. Nevertheless, in certain cases researchers still need oral data (interview), especially for the benefit of confirmation and understand the frame of mind.

The data of this study was categorized into primary and secondary. Primary data can be classified into: first, those were arranged by the official figures (Amir) HT. These works were largely drafted by the originator of Hizb al-Tahrir, Taqiy al-Din al-Nabahani (1909-1977), and by his succesor; 'Abd al-Qadim Zallum (d.2003). Most of these works have been translated into Indonesian. In the new editions, the publisher often add texts as explanation. This rewriting method was called as tabanny; while the books were called as the mutabannat. In this case, they included the explanation to the main texts. They usually noted at the first page with: "wa mà huwa yulgiy khālafahu" (revised edition). ${ }^{24}$ So, these kind of books were

\footnotetext{
${ }^{22}$ Anton Bakker and Ahmad Haris Zubair, Metodologi Penelitian Filsafat, Yogyakarta: Kanisius, 1994, 8.

${ }^{23}$ Bruce L. Berg, Qualitative Research Methods for the Social Sciences, Boston: Allyn and Bacon, 1998, 3.

${ }^{24}$ M. Shiddiq Al Jawi, "Kitab Baru Hizbut Tahrir untuk Menyongsong Berdirinya Khilafah," in http://khilafah1924.org/index2.php?option=com content\& do $p d f=1 \& i d=114$. Downloaded at $3 \mathrm{r}^{\mathrm{d}}$ Agust 2012.
} 
intended to enhance and to replace (in some parts) the previous one.

Second category of the primary data is the works of HTI's members; especially those who have concentrated on Islamic political economy. Among them are Ismail Yusanto (HTI's spokesman), ${ }^{25}$ Dwi Condro Triono (DPP officials), ${ }^{26}$ Muhammad Siddiq Al Jawi (DPP officials), ${ }^{27}$ Muhammad Riza Rosadi (a chairman of DPP HTI), Hafiz Abdurrahman (a former DPP HTI), ${ }^{28}$ and the others. In addition, this research also used the articles written by HTI cadres who wrote in the Al-Wa'ie Journal, ${ }^{29}$ and articles which were presented at the conferences held by HTI. ${ }^{30}$ In addition to the printed works, researcher also used the soft copy data obtained from HTI official websites, as well as from other websites which were commonly used. The secondary data were the works of the early writers who examined HTI. In addition, the secondary source also refered to the works about political economy in general.

${ }^{25}$ M. Ismail Yusanto wrote books: Islam Idiologi - Refleksi Cendekiawan Muda, Bangil: AlIzzah, 1998; Dinar Emas, Solusi Krisis Moneter, Jakarta: PIRAC, 2001; Together with M. Arif Yunus wrote, Pengantar Ekonomi Islam, Bogor: Al-Azhar Press, 2009; Together with Muhammad Karebet Widjajakusuma wrote, Menggagas Bisnis Islami, Jakarta: Gema Insani, 2002; and Pengantar Manajemen Syari'ah, Surakarta: Perisai Pustaka Utama, 2000.

${ }^{26}$ He wrote, Ekonomi Islam Madzhab Hamfara, Np.: Irtikaz, 2012; and some articles.

${ }^{27} \mathrm{M}$. Shiddiq was also a lecturer of Islamic economics, Islamic law consultan at Media Umat Jakarta. He wrote some books, such as, Malapetaka Akibat Hancurnya Khilafah, Bogor: Al Azhar Press, 2004; together with Farid Wadjdi wrote, Ilusi Negara Demokrasi, Bogor: Al Azhar Press, 2009.

${ }^{28}$ He wrote some books, such as, Muqoddimah Sistem Ekonomi Islam, Bogor: Al Azhar Press, 2011 and Diskursus Islam Politik dan Spiritual, Bogor: Al Azhar Press, 2012.

29 The first publication was at 2000 , printed out more than 100.000 copies. The contributors of this journal were HTI leaders and scholars from all over Indonesia. It is more intended to target intellectuals. It is different with Al-Islam, which is aimed to the general public (usually distributed freely in the mosques before or after Friday prayers). HTI also publish a magazine, Khilafah and weekly bulletin, Al-Islam.

${ }^{30}$ Researcher participated in three important seminars which were related to this project; 1. Conference of the Ummah Leaders (Konferensi Tokoh Umat) "Khilafah Model Terbaik Negara yang Menyejahterakan,” in Masjid Agung Central Java, Semarang, $3^{\text {rd }}$ June 2012; 2. Conference of the Ummah Leaders held in Muhammadiyah University of Yogyakarta, $10^{\text {th }}$ June 2012; and 3. Islamic Conference 1435H "Indonesia Milik Allah, Saatnya Menggantikan Demokrasi dan Sistem Ekonomi Liberal," at Stadion Manahan, Surakarta, $1^{\text {st }}$ June 2014. 
An idea was influenced by certain socio-political conditions. It can not be separated from the historical aspects. It was also influenced by the social and intellectual factors, both internal and external. Therefore, the socio-historical approach should be used to achieve a comprehensive understanding of the HTI thoughts.

The collected data were analyzed by deductive-inductive method of thinking. In this case, the writer used the hermeneutic approach. ${ }^{31} \mathrm{I}$ adopted Hanafi's method which states that a meaning was not inherent in the text itself. ${ }^{32}$ It was resulted from the contextual encounter between the text and humans being as the political beings. It was produced in the social and political context in which the text was produced, read and used. When the text has been read and re-interpreted, there was a new meaning reproduced by another individuals and social groups (organizations).

The interpretation of the meaning of the written and unwritten texts can reveal the realities of their organization. Thus it can be gained understanding of visible and hidden meanings as well as historical and ahistorical aspects, in order to discover the deepest meaning of HTI thinking about political economy.

\section{Hizbut Tahrir in Indonesia}

According to Rahmat, Hizb ut-Tahrir was enter Indonesia for the first time in 1982 by M. Mustafa and Abdurrahman al-Bagdadi. Mustafa is Abdullah bin Nuh's son; a teacher of Pesantren Al-Gazali (Bogor, Indonesia), and a lecturer at the Faculty Literature of Indonesia University.

${ }^{31}$ According to Bleicher, hermeneutic is a theory or philosophy of meaning interpretation. See, Josef Bleicher, Contemporary Hermeneutics as Method, Philosophy and Critique, London, Boston and Henley: Routledge \& Kegal Paul 1980, 1.

${ }^{32}$ Hassan Hanafi, "Qira'at al-Nas" in Dirasat Falsafiyyah, Kairo: Anjlaw al-Micriyah, $1987,528$. 
Mustafa was graduated from Jordan university. Abdurrahman came from Lebanon. He migrated to Australia, and later has been lived in Indonesia by the request of Abdullah bin Nuh to become a teacher at the school. ${ }^{33}$ When studied in Jordan, Mustafa started to learn Hizb ut-Tahrir. At that time, it still became an underground missionary movement. Then he has been actived in the organization. His interest to this movement came from his reading of a Nabahani's work entitled Hadarah al-Islamiyya (Islamic civilization) which was given by his father before leaving for Jordan.

Inadvertently, Mustafa met activists of HT in Jordan, and got a chance to read the other Nabhani's books. Reading of the ideas of Hizb ut-Tahrir's founder made him increasingly admired to the thoughts. Then he decided to join Hizb ut-Tahrir. One of Mustafa's interest in this movement was the fact that although they had always been under state pressure, Hizb ut-Tahrir had never provoked to commit violence actions. Their main activity was to spread Islamic thoughts, theology and ideology to strengthen the activities of people through halqah.

The second figure who carried HT to Indonesia, Abdurrahman alBagdadi, had been active in Hizb ut-Tahrir movement since 15 years old. ${ }^{34}$ With his family, he moved to Australia and became an Australian citizen. In Australia, he met Abdullah bin Abdurrahman Noah who was visiting his son studying in Australia. Impressed by his religious ideas, who was then just 25 years old, Abdullah invited him to Indonesia and recognized as his own child. He was asked him to develop the pesantren al-Ghazali in Bogor. He had many opportunities to interact with the IPB students. They had developed Islamic activities in the Masjid al-Ghifari. Their meetings of Islamic studies were then used by Abdurrahman to

${ }^{33}$ Rahmat, Arus Baru Islam Radikal..., 97-99.

${ }^{34}$ Based on the interview with DPD HTI Solo Raya, Juni 3rd, 2012, Abdurrahman was in the condition between "two position": out and excluded from HTI because of his opinions were not in line with HT's vision anymore. 
introduce Hizb ut-Tahrir's ideas to the activists of al-Ghifari mosque.

In 1982 Mustafa took a sabbatical semester. He used this vacation to return to Indonesia. He taught the HT's ideas to the IPB students who stayed at Pesantren al-Ghazali. Fathul Hidayah was one of the students who first came to know and explore the ideas of Hizb ut-Tahrir. He played an important role in the movement and development of HT in the early days.

Through his father, Mustafa was introduced to Abdurrahman, an activist of Hizb ut-Tahrir. Together with Fathul Hidayah, they have been conducted studies on the thinking of Hizb ut-Tahrir by involving other students. Hizb ut-Tahrir ideas which were introduced by Abdurrahman and Mustafa got positive appreciation among the students of Al-Ghazali Schools.

After Mustafa return to Jordan, Fathul Hidayah and his friends (Asep Saifullah, Adian Husaini, Rifai Hasan al-Faridi), continued to holding halqah activities, socializing and networking under the guidance of Abdurrahman. They spread Hizb ut-Tahrir ideas to various areas through a network of campuses in various cities in Indonesia. HTI worked as an underground organization led by Abdullah bin Nuh until his death in 1987, then he was replaced by Mohammed al-Khaththath, and subsequently by Hafiz Abdurrahman.

\section{The relationship between religion, state and economy}

Islam considers the state interference in the economy as a liability. According to Baqir al-Sadr, as quoted by Chapra, it is necessary to ensure the economic alignment with Islamic norms. ${ }^{35}$ In this case, the government has a role to provide a variety of public goods to promote the development and welfare of the community through the public and fiscal policy.

${ }^{35} \mathrm{M}$. Umer Chapra, Islam and the Economic Challenge, USA: The International Institute of Islamic Thought, 1995, 217. 
Public finance is one element of public policy study that consists of a series of interconnected choices made by the government. The policy has been formulated in a variety of fields that lead to welfare issues associated with the values of economic, social, politics and culture. ${ }^{36}$ The form of policy is determined by a group or individual who has access to the policy formulation. The stakeholders are citizen groups, labor unions, political parties, government agencies, elected leaders, policy analysts and others. They have different perceptions of the same information about the policy environment.

Policy environmen $t$ is a particular context in which the events occur around it. Thus, it is influenced by policy makers and public policy. In that dialectical relationship, the objective and subjective dimensions of policy making can not be separated in the real practice. A policy system is the product of subjective conscious choices. It is an objective reality that is manifested in the observed actions and consequences. Policy stakeholder is a product of the system. According to HT, the three components of the economic policy must always be guided by the sharia.

The complexity of the public finances becomes greater by the shifting of Dawla Islam. It became the reason that it is not all sources of state revenue and expenditure to be set in line with the Qur'anic texts. In this case, there are many issues that must be decided by new legal reasoning (ijtihad). It needs to take contextuality into the consideration. ${ }^{37}$ The first person who has a courage to do this contextualization was Caliph Umar ibn al-Khattab. He was the first one who established outposts of the new public finance revenues which never worn before. ${ }^{38} \mathrm{He}$ also decided not to

\footnotetext{
${ }^{36}$ William M. Dunn, Pengantar Analisis Keuangan Publik, Yogyakarta: Gadjah Mada University Press, 1999, 110.

${ }^{37}$ Khalaf, Al-Siyāsah al-Shar'iyyah..., 102-103.

${ }^{38}$ For example, in the field of charity (as one source of revenue at the time) for horse, war (grass herbs for cosmetic ingredients), rubber, marine products and so on. See also Ugi
} 
provide the conquered land for the troops, but let it for the original owner. Nevertheless, they have an obligation to pay the jizya tax. ${ }^{39}$ He also set a levy 'ushur to residents Manbij (Hierapolis). ${ }^{40}$

Pre-existing Islamic traditions and practices can be accepted as long as it is not in contrary with the provisions of Islam. This was exemplified by the Prophet himself. Recent practices could be adopted with certain modifications as long as it is in line with maquạid al-Shari'ah. Based on these considerations, it can be understood that Caliph Umar received future land taxation statutes Sasaniyah after revising rates, collection and administration of the tax. Therefore, Umar has handed over the land to the tenants and has made it as Muslims public ownership and set the taxes, which has been called kharaj, on the land. ${ }^{41}$ Caliph Umar felt also the need to re-contextualized some public finance policies that have been imposed at the time of the Prophet Muhammad, such as the policies regarding to the land distribution (ghanimah). At the early Islam, the conquest land will be distributed one-fifth for the government and social needs (this part was known as khums). While the rest were distributed to those who fought (the troops).42

In his book, Nabhani states that in a Caliphate system, the public and economic policies should apply kharāj and jizya as a source of revenue. Jizya is a tax for the non-Moslem residents as their obligations to the government. They will obtain the right of life and property protection from the state. ${ }^{43}$ This tax will not be charged anymore if they had em-

Suharto, Keuangan Publik Islam: Reinterpretasi Zakat dan Pajak, Yogyakarta: PSZ STIS, 2004, chap. 6.

${ }^{39}$ Yusuf, Kitāb al-Kharāj, 23-27, 35, 68-69, and 140-141. See also, Abu Ubayd, Kitāb alAmwāl, Beirut: Dar al-Kutub, 1986, 65.

40 Yusuf, Kitāb al-Kharāj..., 26-27.

${ }^{41}$ Ubayd, Kitāb al-Amwāl..., 65.

${ }^{42}$ The provision of this division was based on Q.S. Al-Anfal (8): 41.

${ }^{43}$ Zallum, Al-Amwāl fi Dawlah al-Khilāfah..., 40. 
braced Islam. ${ }^{44}$ The provisions of jizya are different from kharāj. It has been set for anyone (both Muslim and non-Muslim) who lived in the conquered land (expansion area) either through war or peace treaty. ${ }^{45}$ In this case, citizens are required to pay kharaj taxes with the assumption that they have been occupying the government lands.

\section{The establishment of public finances according to HTI}

The character of todays "Western" economy is based on positivism and scientism. This framework supports the perspective which focuses on visible-empirical material senses and prioritize the variables that can be measured. This idea establishes to the economics view that "Unmeasurable thing can not be analyzed". As a result, there are many neglected important issues, such as normative and ethical things. Even the proponents of this methodology tends to be neutral from ethical and moral values. Their main concern is how to enlarge the national income becomes the main issues that always be discussed by policy makers. Their mindset is positivistic science.

In HTI's views, the orientation of the capitalist economy is a consequence of their epistemology which does not consider the ethical and religious values. This becames the criticism focus in HTI's course of political economy. According to them, Islamic economic has an advantage in compared from secular economic system in terms of the ideological foundation (the ethical values). ${ }^{46}$ They have stated explicitly that Islamic economic system should not be separated from the spiritual aspect. It is a reflection of the Islamic faith as a principle of the Islamic economic system." ${ }^{47}$

\footnotetext{
${ }^{44}$ Taqy al-Din al-Nabhani, The Economic System of Islam, London: Al-Khilafah Publications, 1997, 228-229.

45 Taqy al-Din al-Nabhani, The Economic System of Islam..., 230.

${ }^{46}$ Anonim, Menegakkan Syariat Islam, Jakarta: Hizbut Tahrir Indonesia, 2002, 66.

${ }^{47}$ Anonim, Menegakkan Syariat Islam..., 166.
} 
The focus of the political economy of capitalism is how to improve the national well-being (wealth and material prosperity) through market mechanisms. ${ }^{48}$ In other words, the accumulation of capital through the market has become the objective. At the same time, it can also indicate the success of this economic system. Ideology underlying economics proposes a typical assumption about human nature merely as a homo economicus, who behaves like a "utility-maximizing machine" equipped by rationality. In the frame of self-oriented, there is no place for morality and ethical considerations. It is underlined by public economic policy in the capitalist system. ${ }^{49}$

Theoretically, state intervention in the economy can only be accepted when the market mechanism does not run properly. In addition, it was needed to address externalities and for the procurement of public goods. Adam Smith argues that since everyone is pursuing their personal interests, it will increase the interest of the public (macro). It will lead into the harmony between individual and common interests. But the reality in any country shows that the economy can not be run properly just by giving it up to the interaction between producers and consumers. In Chapra analysis, it will create social Darwinism. On the one hand, capitalism can indeed create growth, but on the other hand it also produces poverty. ${ }^{50}$ That is, economic growth will be enjoyed merely by the owners of capital, while most people still live in poverty. HTI spokesman has calculated that (in Indonesia), capitalism is simply of $1 \%$, by the $1 \%$, for the $1 \% . . .1^{51}$

48 Al-Nabhany, Nizām al-Islām..., 28-29.

${ }^{49}$ M. Teresa Lunati, Ethical Issues in Economics: From Altruism to Cooperation to Equity,, London: Mac Millan Press, 1997, 139-140.

${ }^{50} \mathrm{M}$. Umer Chapra, Islam and the Economic..., 31.

${ }^{51}$ M. Isma'il Yusanto, "Model Pembangunan Ekonomi Islam yang Tumbuh, Stabil, dan Menyejahterakan," in Ummah Leaders Conference: Best Model Khilafah State Welfare, at UMY, Juni 10th, 2012. 
According to HTI, the drawback of the current capitalist economic system is on the way to elimination of poverty. It focuses solely to increase production (on total production and per capita income), rather than on the problem of distribution. For example, the economy of a country may grow quickly, but it is counted aggregately, without considering the distribution. Therefore the capitalist economic system will never solve the real problem of poverty. It is because the central point of the problem, i.e, the distribution of wealth, never got a touch. ${ }^{52}$

In the Islamic economics discourse, state intervention in the economy is a necessity. For this reason, HT calls Caliphate state in terms dawlah ri'ayah (state which deals with the life of the people). ${ }^{53}$ The intervention is needed to ensure the economic alignment with the Islamic norms. ${ }^{54} \mathrm{In}$ this case, they have a role to provide public goods to encourage the development of public welfare. Especially it is on public service obligation (PSO), namely education, health, and infrastructures (roads, bridges, electricity, water, telephone, etc.). ${ }^{55}$

Distribution becomes the main issue of Islamic political economy because it is not on the matter of production as in the conventional economics. State intervention in the economy gets a large portion in Islamic view. It can not be equated with the socialism. For example, production activities are held by individual; so it does not belong to the state. Thus, there is no role for the state regarding these projects. The government has only a responsibility to ensure the freedom of market access for every individual. For example, the state must provide subsidies for poor farmers so that they can enter into the market of agricultural production.

\footnotetext{
52 Anonim, Manifesto Hizbut Tahrir untuk Indonesia, ncp.: HTI, 2009, 23.

53 Anonim, Manifesto Hizbut Tahrir..., 23.

${ }^{54}$ Chapra, Islam and The Economic..., 217.

${ }^{55}$ Anonim, Manifesto Hizbut Tahrir..., 27.
} 
The government has a responsibility for handling infrastructure projects and public facilities by considering the balance laws (ahkām al-muwāzanah). The law also requires that all matters related to the public interest and common ownership should be controlled by the state. It can not be managed by private sector and individuals. In contrast, production activities that are not associate by public ownership are categorized as invididual. The government is allowed to have it. Therefore, despite the development of some projects that have a universal implementation, it must also comply with the provisions of sharia, i.e by focusing its ownership.

The ultimate ideals of HT are to re-establish the dawlah Khiläah, including the idea of establishing bayt al-mal, as a center of coordination mechanisms and the provision of public goods. By seeing the urgency of bayt al-mál in the state system, HT scholars have formulated the various provisions on state property, sources of income and expenditure headings. In this case they have set up the treasures which become the Muslims rights. They have also formulated the state's responsibilty to spend treasures. Bayt al-māl can be understood as an agency management posts of property income and expenditure. They categorize state income into three sectors; fay and kharaja, common property, and charity sector.

Authorities of public policy have a competence to picking up collections from the citizen in accordance with the discretion, for example, customs and taxes. Regarding to the distribution, the government has also an obligation to take measures of public finance (expenditure allocation) in accordance with sharia. ${ }^{56}$ HT strongly emphasizes sharia compliance as something fundamental and crucial. Without these conditions, citizens do not need to comply and cooperate with government. ${ }^{57}$ The

\footnotetext{
56 Yusanto and Yunus, Pengantar Ekonomi Islam..., 316-317.

${ }^{57}$ Yusanto and Yunus, Pengantar Ekonomi Islam..., 317.
} 
compliance to the provisions of sharia becomes the main objective of the authorities.

Generally, sharia provisions regarding to the state spending are determined as follows:

1. Treasures from zakat (charity) sector is managed specifically in bayt al-māl, which is reserved for the poors (eight așnaf).

2. Bayt al-mâl income can be allocated for the benefit of the general welfare (mașlahah), for example, to reduce poverty.

3. Bayt al-măl can spend income for the emergency cases, such as famine, floods and earthquakes.

4. Bayt al-māl revenue can be used for a compensation (badal and ujrah), such as the salaries of soldiers, civil servants, judges, lecturers, and so on.

5. Management of common property sector should not be confused with other revenue sectors. Because it is the right of all Muslims that the caliphate based on ijtihad allocated by the considerable benefit of Muslims.

According to HT, an Islamic state must ensure that all economic activities, concerning to the production, distribution and consumption of goods and services, have been implemented in accordance with the sharia provisions. There is no one nor a party who was oppressed or oppressing. Therefore, Islam has decreed laws relating to economic activities (production, industry, agriculture, distribution, trade, investment, monetary, taxation, and so on), which allows everyone to have an equal access to get goods. Besides using public policy, dawla caliphate can also use non-economic patterns for redistributing wealth to those who do not have access to a good economy, through instruments such as zakat, sadaqah, grants and state administration.

Based on the above perspective, the distribution in the real sector can be interpreted as an attempt to allocate resources, so that the welfare can 
be felt widely. It means that the distributions are resulted from an economic activity, such as buying and selling activities and work fields (effort and reward). Even the perpetrators of the distribution will be the dominant economic players in addition to consumers and producers. For this reason, Islamic economics puts this sector in a strategic position in the economic mechanism.

Essentially, the function of economic distribution is to give bridge between consumers and producers interests; based on the tenet of maslahah (common good). The distribution should be conductive to satisfy the motif of the interests of both consumers and producers. Then it is expected to fulfill the rights and obligations which have been determined by law for consumers and producers. Thus, the distribution activities should be in line with the main objective of the motives and activities of production and consumption. It is the fulfillment of the needs of the wider community based on common good.

The basic need for every individual is to earn a decent life. It also becomes the main goal of the economic system. In economic activities, each individual must be guaranteed to meet the basic needs, including food, clothing, residence, health and education. The guarantee to fulfill the basic needs becomes the determining factor of economic stability, political and social life.

The HT's concept of economic distribution justice is different from the equality and equity of socialism. It is also completely different from capitalism, where justice distribution does not become a concern. According to HT, this was resulted from their "benchmarks". The indication of the economic development success is merely seen from the increase of per capita income. In fact, the increase of per capita income (if any), is simply the average calculation. Many countries often have a very high income increase, but in fact it has only been captured by a few popu- 
lation. While the majority does not share on it at all, in fact it may be much decreased.

\section{Conclusion}

HTI's economic and political thoughts have been structured very well. There are almost no dynamics of idea. This has been due to a good coordination and control to the key concepts of their idea. The form of "thought control" has been done by way of preparation of the tabanny books by the HT's emirs, especially Nabhaniy and Zallum. The books are firmly implanted in the minds of the Hizbiyyun (HT members) through routine coaching (halqah).

HT concept of political economy can not be separated from the Nabhaniy concept of economics. He classifies it into the pure science and the economic systems. The object of the economics study is productivity of goods and services. So it is a universal science. In another words, this can not be separated from the development of economic science in general (conventional). While the study of economic system covers about ways to acquire, utilize and distribute goods and services. So, it is influenced by a particular ideology or worldview.

Based on HTI's epistemology, economic system is not merely proposed as an alternative, but as a substitute one. Islam is presented as a total change to the existing system, ranging from the economics philosophy, production and distribution. The logical consequence of this concept is the need for fundamental changes to the economic system of the Western concept and practice

According to HT, the basic principles that should be considered in establishing the Islamic economic system comprises of three things: 1) Ownership (al-milkiyah); 2) Management of property (tașarruf fi al-milkiyah); and, 3) Distribution of wealth (tawzi' al-tharwah bayn al-Nas). One type of 
the state ownership is defined as a property of all Muslims. It's management is under the authority of the state. Actually, this property is classified as an individual treasure ( $f a r d\}$ iyah), but it contains the benefit for all people. Based on its nature, this property can not be owned individually. It can not also be categorized as a public property, but it belongs to the state. Consequently, its management belongs to the government.

The most important issues related to the discussion of public finance management of state finances is that HT tends to see every current economic problem by reflecting it into the cultural heritages of the past. Related to this, the slogan that they have always shouted is "Back to the caliphate" or "Sharia is the only solution..." From this philosophy it can be estimated that HT thoughts of Islamic public finance, will face the problem of contextualization.

\section{Bibliography}

Ahmed, Houriya dan Hannah Stuart. Hizb ut-Tahrir, Ideology and Strategy. London: The Centre for Social Cohesion, 2009.

Ahnaf, Mohammad Iqbal, "From Revolution to "Refolution": A Study of Hizb al-Tahrir, Its Changes and Trajectories in the Democratic Context of Indonesia (2000-2009)," Ph.D Thesis at Program Strategic Studies, Victoria University of Wellington, New Zealand, 2010.

Ahnaf, Mohammad Iqbal, "The Image of the Enemy, Fundamentalist Muslims' Perceptions of the Other (Majelis Mujahidin Indonesia and Hizbut Tahrir Indonesia)", Thesis presented at Postgraduate Programme of Center for Religious and Cross-Cultural and Studies, Universitas Gadjah Mada, 2004.

Ahnaf, Muhammad Iqbal, "MMI dan HTI; The Image of The Others," in A. Maftuh Abegebriel and A. Yani Abeveiro, (ed.). Negara Tuhan: the Thematic Encyclopedia. Yogyakarta: SR-Ins, 2004. 
Al Jawi, M. Shiddiq, "Kitab Baru Hizbut Tahrir untuk Menyongsong Berdirinya Khilafah," in http://khilafah1924.org/index2.php?option=com content \& do $\mathrm{pdf}=1 \& \mathrm{id}=114$. Downloaded at $3 \mathrm{r}^{\mathrm{d}}$ Agust 2012.

Al-Nabhaniy, Taqiy al-Din. Nizăam al-sslām. Beirut: Dār al-Ummah, 2001.

Al-Nabhaniy, Taqiy al-Din. The Economic System of Islam. London: Al-Khilafah Publications, 1997.

Al-Nabhaniy, Taqiy al-Din. The Economic System of Islam. London: Al-Khilafah Publications, 1997.

Anonim. Manifesto Hizbut Tahrir untuk Indonesia. Np.: HTI, 2009.

Anonim. Menegakkan Syariat Islam. Jakarta: Hizbut Tahrir Indonesia, 2002.

Arifin, Syamsul, "Obyektivikasi Agama sebagai Ideologi Gerakan Sosial Kelompok Fundamentalis Islam (Studi Kasus Hizbut Tahrir Indonesia di Kota Malang)", Ph.D Thesis at IAIN Sunan Ampel, Surabaya, 2004. Bakker, Anton and Ahmad Haris Zubair. Metodologi Penelitian Filsafat. Yogyakarta: Kanisius, 1994.

Berg, Bruce L. Qualitative Research Methods for the Social Sciences. Boston: Allyn and Bacon, 1998.

Bleicher, Josef. Contemporary Hermeneutics as Method, Philosophy and Critique. London, Boston and Henley: Routledge \& Kegal Paul 1980.

Chapra, M. Umer. Islam and the Economic Challenge. USA: The International Institute of Islamic Thought, 1995.

Dunn, William M. Pengantar Analisis Keuangan Publik. Yogyakarta: Gadjah Mada University Press, 1999.

Hanafi, Hassan, "Qira'at al-Nas" in Dirāsat Falsafiyyah. Kairo: Anjlaw al-Micriyah, 1987.

Khalaf, 'Abd al-Wahhab, al-Siyāsah al-Shar'iyyah. al-Munirah: Matba'ah alTaqaddum, 1977. 
IJIMS, Indonesian Journal of Islam and Muslim Societies, Volume 4, Number 1, June 2014: 105-134

Kurniawan, Hendra, "Realitas Gerakan Hizbut Tahrir di Indonesia: Wacana Hegemonik dan Praksis Ideologi (Studi Pemikiran Islamisme Timur Tengah dalam Peta Gerakan Fundamentalisme Islam-Politik di Indonesia)," Thesis at The Islamic Studies Program of Islamic University of Indonesia, 2010

Lunati, M. Teresa. Ethical Issues in Economics: From Altruism to Cooperation to Equity. London: Mac Millan Press, 1997.

Mubyarto. Pemberdayaan Ekonomi Rakyat dan Peranan Ilmu-Ilmu Sosial. Yogyakarta: BPFE, 2002.

Muhsin, Ilyya, "Gerakan Penegakan Syariat Islam; Studi tentang Gerakan Sosial Hizbut Tahrir Indonesia di DIY" Thesis of Sociology Programme of Gadjah Mada University, 2007.

Nashir, Haedar. Gerakan Islam Syariat: Reproduksi Salafiyah Ideologis di Indonesia. Jakarta: PSAP Muhammadiyah, 2007.

Qodir, Zuly, "Fundamentalisme Islam, Memahami Penyebab dan Karakter Gerakan" in Potret Retak Nusantara: Studi Kasus Konflik di Indonesia. Yogyakarta: CSPS, 2004.

Rahmat, M. Imdadun. Arus Baru Islam Radikal: Transmisi Revivalisme Islam Timur Tengah ke Indonesia. Jakarta: Erlangga, 2005.

Rahmat, M. Imdadun. Arus Baru Islam Radikal: Transmisi Revivalisme Islam Timur Tengah ke Indonesia. Jakarta: Erlangga, 2005.

Rofiq, Ainur. Membongkar Proyek Khilafah ala Hizbut Tahrir di Indonesia. Yogyakarta: LKiS, 2012.

Rosadi, Muhammad Riza. Diskursus Islam Politik dan Spiritual. Bogor: Al Azhar Press, 2012.

Rosadi, Muhammad Riza. Muqoddimah Sistem Ekonomi Islam. Bogor: Al Azhar Press, 2011. 
Shiddiq, M. and Farid Wadjdi. Ilusi Negara Demokrasi. Bogor: Al Azhar Press, 2009.

Shiddiq, M. Malapetaka Akibat Hancurnya Khilafah. Bogor: Al Azhar Press, 2004.

Suharto, Ugi. Keuangan Publik Islam: Reinterpretasi Zakat dan Pajak. Yogyakarta: PSZ STIS, 2004.

Sumbulah, Umi, "Islam Radikal dan Pluralisme Agama: Studi Konstruksi Sosial Aktivis Ḥizb al-Taḥrîr dan Majelis Mujahidin di Malang tentang Agama Kristen dan Yahudi”, Ph.D Thesis at IAIN Sunan Ampel Surabaya, 2007.

Team of Hizbut Tahrir Indonesia. Mengenal Hizbut Tahrir Partai Politik Islam Idiologis. Bogor: Pustaka Thariqul Izzah, 2002.

Triono, Dwi Condro. Ekonomi Islam Madzhab Hamfara. Np.: Irtikaz, 2012.

Ubayd, Abu. Kitāb al-Amwāl. Beirut: Dār al-Kutub, 1986.

Yusanto, M. Isma'il, "Model Pembangunan Ekonomi Islam yang Tumbuh, Stabil, dan Menyejahterakan,” in Ummah Leaders Conference: Best Model Khilafah State Welfare, at UMY, Juni 10th, 2012.

Yusanto, M. Ismail and M. Arif Yunus. Pengantar Ekonomi Islam. Bogor: AlAzhar Press, 2009.

Yusanto, M. Ismail and Muhammad Karebet Widjajakusuma. Menggagas Bisnis Islami. Jakarta: Gema Insani, 2002.

Yusanto, M. Ismail. Dinar Emas, Solusi Krisis Moneter. Jakarta: PIRAC, 2001.

Yusanto, M. Ismail. Islam Idiologi-Refleksi Cendekiawan Muda. Bangil: Al-Izzah, 1998.

Yusanto, M. Ismail. Pengantar Manajemen Syari'ah. Surakarta: Perisai Pustaka Utama, 2000.

Yusuf, Abu. Kitāb al-Kharāj. Kairo: Maktabah Salafiyah, 1382H. 
IJIMS, Indonesian Journal of Islam and Muslim Societies, Volume 4, Number 1, June 2014: 105-134

Zallum, 'Abd al-Qadim. Al-Amwāl fi Dawlah al-Khilāfah. Dār al-'Ilmi li alMalāyin, 2004.

Zallum, 'Abd al-Qadîm. The Methodology of Hizbut Tahrir for Change. London: al-Khilafah Publications, 1993.

Zulkarnain, Iskandar, "Arena Kekuasaan Simbolik Hizbut Tahrir Indonesia (HTI) dan Majelis Mujahidin Indonesia (MMI) Pasca Orde Baru," Thesis presented at Sociology Programme of Gadjah Mada University, Yogyakarta, 2009. 